\title{
Growth performance of white, black and bronze color heritage turkeys under semi-intensive system
}

\author{
$\bowtie$ Shubash Chandra Das, Md. Yahya, Md. Shamim Hasan, Md. Altaf Hossain, Tanzina Akter and \\ Mahbuba Sultana
}

Department of Poultry Science, Bangladesh Agricultural University, Mymensingh-2202, Bangladesh

ARTICLE INFO open ${ }^{\text {access }}$

Article history:

Received: 07 August 2018

Accepted: 02 October 2018

Published: 31 December 2018

Keywords:

Heritage turkey; color type,

semi-intensive; production

Correspondence:

Shubash Chandra Das

凶: das_poultry@yahoo.com

\begin{abstract}
The present study was conducted to compare the growth performance of White, Black and Bronze color type of turkeys, which have been currently introduced in Bangladesh. The birds were reared under semiintensive system at BAU Poultry Farm with supplementation of commercial broiler grower and layer feeds. Key objectives were to investigate the growth performance of locally found turkeys (known as heritage turkeys) under semi-intensive rearing system and to recommend turkey as a supplementary part of existing poultry business in the country. A total of 46 poults of White, Black and Bronze color type unsexed birds of 5 weeks age were housed. Birds were reared under similar management conditions and feeds were purchased from local market. No significant difference $(p>0.05)$ in live weight for three color types were found. At the end of 21 weeks rearing, Bronze type turkeys attained highest live body weight $(3720.71 \mathrm{~g} / \mathrm{bird})$ while White type turkeys attained lowest $(3282.29 \mathrm{~g} / \mathrm{bird})$. The Black type turkeys however, attained $3552.86 \mathrm{~g} /$ bird body weight. The live weight gain was increased gradually but decreased again after 18 weeks of age. Weekly weight gains were highest in all color types at 18 weeks of age where white type male turkey attained the highest $(440.71 \mathrm{~g} / \mathrm{bird})$ and black type showed the lowest weight gain (345.00g/bird). No significant difference $(\mathrm{p}>0.05)$ in FCR among the three color types were found. Survivability under semi intensive system of three different color types, White, Black and Bronze were $100 \%, 88.46 \%$ and $91.67 \%$ respectively. Taken together, the growth performance of Bronze type turkey was superior to other color types used in this experiment. Therefore, it can be concluded that turkey farming will viable in Bangladesh with available local varieties under semi-intensive system through feeding of commercial broiler and layer feeds.
\end{abstract}

\section{Copyright:}

(c) (i)

(O2018 by authors and BAURES. This work is licensed under the Creative Commons Attribution International License (CC By 4.0).

\section{Introduction}

Deficiency of poultry meat and eggs in the country are $78.91 \%$ and $65.38 \%$ respectively per person per year (FAO/APHCA, 2012; Saleque, 2010; Das et al. 2008). The commercial poultry sector has got an industrial shape within the period of 3 decades and becomes one of the leading enterprises contributing lot in national economic growth, followed by garments. Among 11 poultry species, only few are available in Bangladesh, of which the chicken is dominant over others and comprises almost $90 \%$ of the total poultry population (Das et al., 2008). In Bangladesh the average number of chickens per household was recorded as 7.0 and the national sharing of commercial poultry to its indigenous counterpart in terms of egg production almost equal i.e., 50:50 and that of meat production is 60:40 (Islam et al., 2015).

Commercial broiler and layer farming have emerged during the last quarter of 20th century and then flourishes within short period. Expansion of poultry farming, both at commercial and domestic levels, is meant absolutely the expansion of modern chicken strains of layer and broiler. In addition to chicken, the other poultry species that traditionally rearing and kept by our rural poultry keepers are quail, geese, pigeon and guinea fowl. The growth, development and expansion of above mentioned species of specialized fowls are remained unchanged for decade after decade as because of a little or no attention has been paid to them.

In such a situation, it may be pertinent to focus on the rearing of alternative poultry species. One of the best choices may be the turkey (Meleagris gallopavo), which has been recently introduced in Bangladesh and slowly expanding in small scale throughout the country. Turkey (Meleagris gallopavo) is a large gallinaceous bird of the family Meleagridae and occupies an important global position next to chicken and duck approximately $5 \%$ of world poultry population (Besbes, 2009). Turkey meat consumption in USA $7.36 \mathrm{~kg} /$ person/year (Statista, 2018). Turkey has been contributing as the most evolving sector in western countries, Europe and America in particular, where it plays a pivotal role in supplying animal protein. The birds are reared for meat purpose only and, as reported, its meat is the leanest among all domestic avian species. Turkey meat has been considered as luxury meat by many consumers. Apart from the role in protein supply, the birds also have an aesthetic value due to their beauty (Ogundipe and Dafwang, 1980). More importantly, turkeys have unique and remarkable phenomena in adaptability to wide range of climatic conditions and can be raised successfully almost everywhere in the world if they are well fed and

\section{Cite this article}

Das S.C., Yahya M., Hasan M.S., Hossain M.A., Akter T. and Sultana M. 2018. Growth performance of white, black and bronze color heritage turkeys under semi-intensive system. Journal of Bangladesh Agricultural University, 16(3): 471-477. 
protected against diseases, predators and adverse weather conditions (Bhanja and Majumdar, 2001).

First instance for the domestication of turkeys was probably in Mexico, from the Mexican sub-species Meleagris gallopavo and was used as a domestic fowl by Indian communities, which is now known as the SouthWestern USA (Ahmed, 2009). The history of turkey production in Bangladesh is very new, and most probably this is the first scientific documentation regarding turkey production in the country. Thus, there is no specific information on how, when and from where turkey production has been started in the country however it can be assumed that the birds entered in Bangladesh through cross-bordering from the neighboring countries. As farmers reported, the birds came to Bangladesh and started to rear in northern and southern parts approximately 7-8 years back. Initially, only handful of farmers who were enthusiastic in rearing specialized fowls kept few pairs of birds as part of their hobby. Later, the birds could quickly be adjusted with local environment and thrive well under very ordinary foods, housing and management. Rearing turkey was not much popular to the general farmers, primarily may be because the birds were not well known to poultry keepers. It is however interesting to note that in recent days good number of farmers became familiar with the birds, rearing 50-200 birds at the home premises and getting benefit by selling poults with high market price. Currently market price of poults is approximately 100 $\mathrm{BDT} /$ poult, which is much higher than the commercial layer (25 BDT/chick), broiler (35 BDT/chick), sonali (15 BDT/chick) and duck (30 BDT/duckling). Since the birds are newly introduced in Bangladesh, the farmers are not well aware about various aspects of rearing such as feeding, housing, prevention and disease management, standard growth pattern, feed efficiency, copulation system, incubation of hatching eggs etc (Asaduzzaman et al. 2017). In present study, few of the above-mentioned issues such as feed consumption, feed efficiency, growth, disease prevention, general management of birds were focused. As reported elsewhere, there are many varieties of turkeys in all around the globe however principal varieties that have attained commercial importance in many parts of the world are, Broad Breasted, Large White and Broad Breasted Bronze. Other varieties are White Holland, Beltsville, Small White, Black, Bourbon Red and Narrangansett (Ogundipe and Dafwang, 1980). In Bangladesh, more than three color of turkeys are available, which may be termed as heritage turkeys.

To our concern, no comprehensive research works have yet been conducted on the characterization of turkey varieties available in Bangladesh, their production status, disease management and extension work. As the consequence, information on most of the production performances are yet unknown. Under the prevailing conditions, current study was designed to investigate the growth performance of locally available three plumage color type turkeys namely white, black and bronze under semi- intensive rearing system.

\section{Materials and Methods}

Birds, house management and experimental plan

The present research was conducted at Bangladesh Agricultural University (BAU) Poultry Farm, Mymensingh. A total of 46 poults having 5 weeks of age were brought from a farmer in Bogra. All the poults were leg banded soon after arrival and data of the individual bird was recorded. Brooding of poults was completed at farmer's house and then the poults were brought to BAU Poultry Farm at 5 weeks of age to observe their growth performance. One experimental room having the area of 400 square feet was partitioned into two parts and half of the area i.e. 200 square feet $\left(20^{\prime} \times 10^{\prime}\right)$ was allotted for 46 birds. Therefore, floor space for each bird was 4.35 square feet. Room was properly washed and cleaned by using tap water. Ceiling, walls and floor were thoroughly cleaned. The whole room area was sanitized with Vircon, a common but effective disinfectant. Before arrival the poults, rice husk was provided as bedding material. Drinkers and feeders were also provided prior to arrival the poults. To acclimatize with the environment, young turkeys were allowed for a short period during day time at outside of the room.

\section{Feeding, watering and immunization of the birds}

All the poults were kept together and fed commercial broiler starter feed (ME-3000 kcal $/ \mathrm{kg}, \mathrm{CP}-23 \%)$ up to 8 weeks of age. Then, the layer grower feed (ME-2800 $\mathrm{kcal} / \mathrm{kg}, \mathrm{CP}-20 \%$ ) was provided up to 21 weeks of age. Feed was supplied twice daily, once in the morning and another at afternoon. Fresh and clean dirking water was made available at all the times. Poults were vaccinated with BCRDV at 3 days of age and booster dose was performed at 18 days of age in the farmer's house against Newcastle disease. Fowl pox vaccine was administrated at $5 \mathrm{wks}$ of age through the puncturing of wing web $(\mathrm{w} / \mathrm{w})$. Then, Nobilis ${ }^{\circledR}$ ND Lasota prepared from the Lasota strain was vaccinated at 2 months of age through drinking water and repeated every two months. The birds were always exposed to natural lighting in day times. No artificial light was provided during the night.

\section{Litter management, sanitation and biosecurity}

Rice husk with the thickness of 2 inches was used as litter materials. As compared to chicken, litter used in turkey became damper quickly, might be because of voluminous droppings. Because of aggressive attitude and fighting movement inside the house, waterers are fall down on the floor and caused wet litter problem, especially around the waterers. Thus, damp and wet litter was changed partially when necessary to maintain litter dry and clean. Strict sanitary and biosecurity measures were taken particularly in and around the experimental unit. 
Records keeping and data analysis

Data on weekly body weight of individual tagged birds, weekly body weight gain, bird's survivability, vaccination and medication records were kept. Records on feed consumption were maintained on weekly basis up to the end of experiment and the feed conversion ratio was calculated by dividing total feed consumption

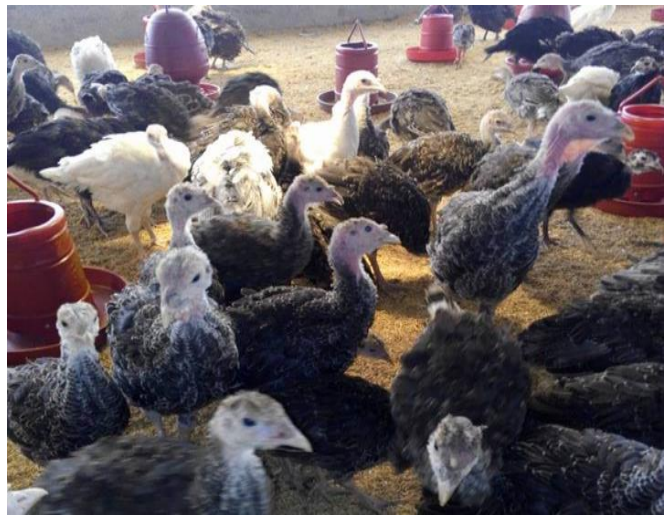

(a) Turkey poults at one month of age

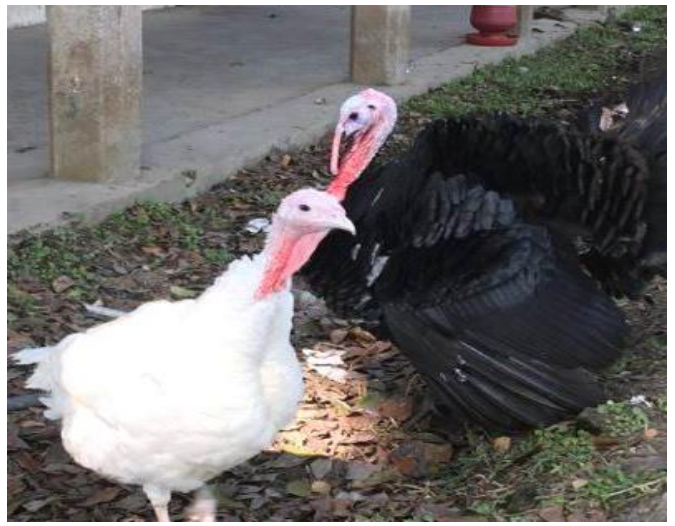

(c) Growing turkeys at 16 weeks of age by average body weight gain. The recorded data were analyzed using General Linear Model (GLM) procedures using one-way ANOVA through SPSS software. All data were analyzed for the completely randomized design. The significance differences were tested using Tukey's test.

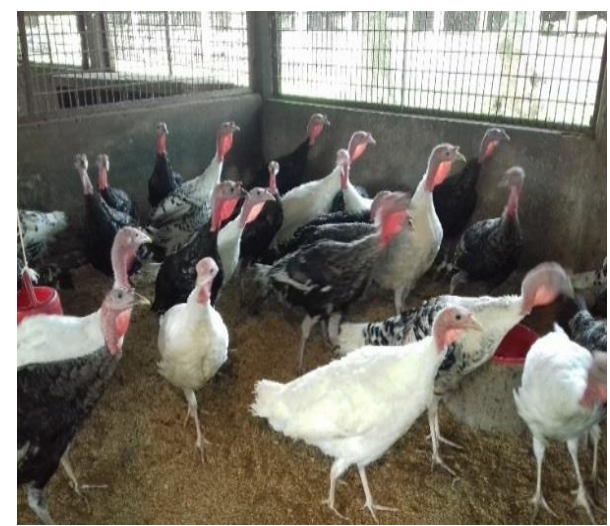

(b) Growing birds at BAU Poultry Farm

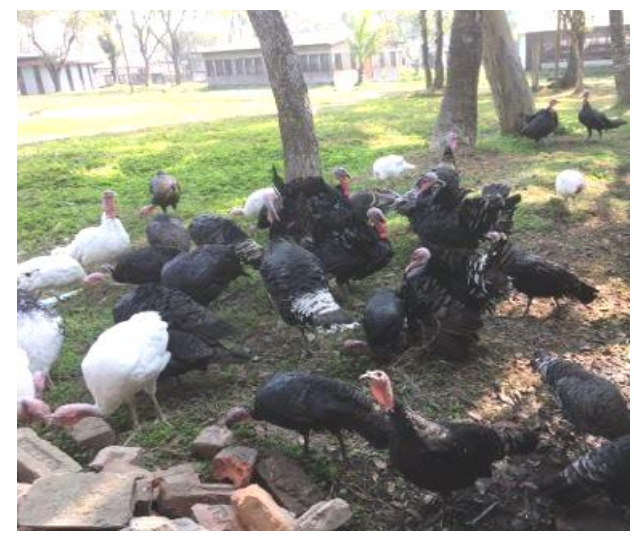

(d) Adult turkeys scavenging at BAU Poultry Farm

Photo: Experimental turkey birds at different ages rearing at BAU Poultry Farm

\section{Results and Discussion}

Production performance of the experimental birds

The results of weekly growth performances such as live weight, live weight gain, feed consumption and feed conversion ratio of the turkeys having distinct plumage color namely Black, White and Bronze are discussed. In Bangladesh, generally the turkey farmers who have parent breeders hatch the eggs using home type electric incubator and sell the poults after completion of brooding. Few farmers also hatch turkey eggs by natural incubation method setting eggs under indigenous broody chicken hen. It's an understanding of parent owners that the small-scale farmers who starts farming with newborn turkeys would be faced challenges in management at early stage. Therefore, the parent owners sell the young poults after completion of brooding period usually 30 days of age so that the new farmers can handle the birds smoothly.

\section{Live weight}

The weekly live weight of three color types namely White, Black and Bronze reared under semi-intensive system with a supplementation of same diet and identical management is shown in Table 1 (male) and Table 2 (female). There were significant differences in weekly live weight among three different color types of male turkey at 20 and 21 weeks of age. Remaining other week of ages showed no significant differences among three color groups but an increasing trend was observed in the body weight of Bronze colored birds compared to others. At 21 weeks of age, Bronze type male turkeys was attained the highest live body weight $(3720.71 \pm 64.96 \mathrm{~g} / \mathrm{bird})$ followed by Black (3552.86 \pm $112.47 \mathrm{~g} / \mathrm{bird})$ and the lowest ( $3282.29 \pm 20.87 \mathrm{~g} / \mathrm{bird})$ was recorded in White color turkeys. 
Table 1. Weekly live weight (g/bird) of White, Black and Bronze color types of male Turkey

\begin{tabular}{lccccc}
\hline $\begin{array}{l}\text { Age } \\
\text { (weeks) }\end{array}$ & White & Black & Bronze & P-value & $\begin{array}{c}\text { Level of } \\
\text { significance }\end{array}$ \\
\hline 5 & $379^{\mathrm{c}} \pm 1.445$ & $386^{\mathrm{a}} \pm 2.492$ & $381^{\mathrm{bc}} \pm 1.782$ & 0.046 & NS \\
6 & $417^{\mathrm{b}} \pm 2.417$ & $445^{\mathrm{a}} \pm 12.865$ & $426^{\mathrm{ab}} \pm 2.781$ & 0.060 & NS \\
7 & $653 \pm 11.813$ & $614 \pm 7.156$ & $610 \pm 27.299$ & 0.154 & NS \\
8 & $704 \pm 15.469$ & $709 \pm 16.064$ & $738 \pm 35.747$ & 0.563 & NS \\
9 & $804 \pm 15.608$ & $798 \pm 31.295$ & $821 \pm 30.889$ & 0.828 & NS \\
10 & $947 \pm 28.442$ & $913 \pm 45.953$ & $1017 \pm 40.873$ & 0.186 & NS \\
11 & $1016 \pm 35.851$ & $1072 \pm 40.123$ & $1153 \pm 43.933$ & 0.380 & NS \\
12 & $1309 \pm 44.327$ & $1274 \pm 47.313$ & $1322 \pm 51.903$ & 0.768 & NS \\
13 & $1526 \pm 52.282$ & $1495 \pm 63.214$ & $1580 \pm 57.076$ & 0.580 & NS \\
14 & $1710 \pm 45.862$ & $1741 \pm 83.193$ & $1842 \pm 52.597$ & 0.368 & NS \\
15 & $1909 \pm 79.616$ & $1984 \pm 94.361$ & $2087 \pm 59.460$ & 0.301 & NS \\
16 & $2205^{\mathrm{c}} \pm 17.930$ & $2237^{\mathrm{bc}} \pm 75.749$ & $2389^{\mathrm{a}} \pm 48.359$ & 0.054 & NS \\
17 & $2605^{\mathrm{b}} \pm 24.967$ & $2617^{\mathrm{b}} \pm 81.517$ & $2781^{\mathrm{a}} \pm 40.404$ & 0.061 & $\mathrm{NS}$ \\
18 & $3045^{\mathrm{b}} \pm 59.048$ & $2962^{\mathrm{ab}} \pm 105.412$ & $3201^{\mathrm{a}} \pm 51.671$ & 0.105 & $\mathrm{NS}$ \\
19 & $3120^{\mathrm{b}} \pm 33.296$ & $3243^{\mathrm{ab}} \pm 105.778$ & $3382^{\mathrm{a}} \pm 39.908$ & 0.045 & NS \\
20 & $3202^{\mathrm{b}} \pm 22.130$ & $3379^{\mathrm{a}} \pm 106.743$ & $3550^{\mathrm{ab}} \pm 50.827$ & 0.009 & $* *$ \\
21 & $3282^{\mathrm{a}} \pm 20.868$ & $3552^{\mathrm{a}} \pm 112.477$ & $3720^{\mathrm{b}} \pm 64.958$ & 0.003 & $* *$ \\
\hline
\end{tabular}

NS $=$ Non-Significant, Values indicate mean \pm Standard Error

Table 2. Weekly live weight (g/bird) of White, Black and Bronze color types of female Turkey

\begin{tabular}{lccccc}
\hline Age (weeks) & White & Black & Bronze & P-value & $\begin{array}{c}\text { Level of } \\
\text { significance }\end{array}$ \\
\hline 5 & $277 \pm 4.530$ & $283 \pm 3.300$ & $286 \pm 2.212$ & 0.219 & NS \\
6 & $381 \pm 4.235$ & $384 \pm 2.7373$ & $388 \pm 3.828$ & 0.416 & NS \\
7 & $432 \pm 9.091$ & $437 \pm 13.683$ & $444 \pm 16.926$ & 0.818 & NS \\
8 & $652 \pm 9.141$ & $661 \pm 16.010$ & $606 \pm 36.843$ & 0.244 & NS \\
9 & $718 \pm 14.469$ & $736 \pm 28.026$ & $664 \pm 46.608$ & 0.291 & NS \\
10 & $843 \pm 13.421$ & $846 \pm 45.953$ & $884 \pm 36.291$ & 0.994 & NS \\
11 & $982 \pm 21.487$ & $982 \pm 52.283$ & $950 \pm 45.005$ & 0.824 & NS \\
12 & $1171 \pm 40.357$ & $1119 \pm 74.147$ & $1081 \pm 53.862$ & 0.552 & NS \\
13 & $1278 \pm 25.096$ & $1309 \pm 84.724$ & $1238 \pm 56.706$ & 0.710 & NS \\
14 & $1438 \pm 24.511$ & $1453 \pm 101.070$ & $1405 \pm 64.077$ & 0.886 & NS \\
15 & $1586 \pm 27.956$ & $1650 \pm 119.583$ & $1625 \pm 82.737$ & 0.871 & NS \\
16 & $1801 \pm 20.555$ & $1815 \pm 128.208$ & $1875 \pm 90.865$ & 0.833 & NS \\
17 & $2021 \pm 14.828$ & $2025 \pm 140.790$ & $2126 \pm 106.583$ & 0.717 & NS \\
18 & $2301 \pm 67.793$ & $2315 \pm 127.967$ & $2434 \pm 126.103$ & 0.653 & NS \\
19 & $2388 \pm 46.948$ & $2339 \pm 160.402$ & $2447 \pm 134.24$ & 0.827 & NS \\
20 & $2466 \pm 52.444$ & $2442 \pm 124.67$ & $2553 \pm 137.937$ & 0.764 & NS \\
21 & $2539 \pm 62.430$ & $2561 \pm 96.543$ & $2645 \pm 144.868$ & 0.679 & NS \\
\hline
\end{tabular}

NS $=$ Non-Significant, Values indicate mean \pm Standard Error

The body weight of White, Black and Bronze color type female turkeys at 21 weeks were $2539.71 \mathrm{~g}, 2561.43 \mathrm{~g}$ and 2645.43g respectively. Karki (2005) conducted an experiment to observe growth performance of turkeys and found an average body weight of $4.525 \mathrm{~kg} / \mathrm{bird}$ for male and $3.3 \mathrm{~kg} / \mathrm{bird}$ for female at 20 weeks of age, although he did not mention the type or variety or color of birds were used for the study. In present study, the results for body weight in all color types were little bit lower than the average body weight observed by Karki (2005). When the hybrid turkeys were used for observation of growth performance, their live weight recorded was much higher, as reported in many published papers (Austic and Neshein, 1990; Waibel et al. 2000; Prasad, 2000). Hybrid converter poults exhibit fast-growing traits and showed as much as body weights of approximately $9.644 \mathrm{~kg}$ at 15 weeks of age (Yilmaz et al. 2011), which is much higher than the body weight found in present study with heritage turkeys. A large variety turkey such as Broad Breasted Bronze even could achieve a body weight of $10.90 \mathrm{~kg}$ at 24 weeks of age (Austic and Neshein, 1990). Almost similar results were reported by Sampath et al. (2012). Marketing age of birds and target body weight of marking are the key factors must consider gaining maximum profit of turkey farming. In other study, Singh and Moore (1972) 
mentioned that the slow growth and poor feed efficiency are the common phenomena for small variety turkey, which is also resembled to the body weight of White color turkey found in present study. Based on the research conducted at Haryana Agriculture University, India the most economical marketing age as mentioned is 16 weeks (Prasad, 2000), however, Singh and Moore (1972) suggested an optimum market age of 20 weeks to obtain maximum profit.

\section{Live weight gain}

Live weight gain of the birds of three different color types is given in Table 3 (male) and Table 4 (female).
There were significant differences among three color types male turkeys found in $7,8,10,19,20$ and 21 weeks of ages (Table 3). On the other hand, three types of female turkeys showed significant differences only at 13 weeks of age (Table 4). Among the three color types, black type male turkeys showed highest weekly body weight gain (173.29 g/day) compared to bronze type (170.71 g/day), followed by white $(80 \mathrm{~g} /$ day $)$ at the 21 weeks of age (Table 3). Similar results also observed in case of female turkeys, where black type turkeys attained highest (118.57 g/day) weekly gain at 21 weeks of age compared to bronze (111.86 g/day), white (73.57 $\mathrm{g} / \mathrm{d}$ ) color types (Table 4).

Table 3. Weekly live weight gain (g/bird) of White, Black and Bronze color types of male Turkey

\begin{tabular}{|c|c|c|c|c|c|}
\hline Age (weeks) & White & Black & Bronze & P-value & $\begin{array}{c}\text { Level of } \\
\text { significance }\end{array}$ \\
\hline 5 & $128 \pm 1.462$ & $129 \pm 2.109$ & $125 \pm 1.343$ & .185 & NS \\
\hline 6 & $38 \pm 1.883$ & $58 \pm 11.152$ & $45 \pm 1.738$ & .116 & NS \\
\hline 7 & $235^{\mathrm{a}} \pm 2.966$ & $169 .^{c} \pm 16.977$ & $183^{\mathrm{b}} \pm 25.131$ & .039 & $* *$ \\
\hline 8 & $51^{\mathrm{c}} \pm 15.079$ & $94^{\mathrm{b}} \pm 13.133$ & $128^{\mathrm{a}} \pm 23.593$ & .022 & $* *$ \\
\hline 9 & $100 \pm 2.213$ & $89 \pm 30.343$ & $82 \pm 10.987$ & .792 & NS \\
\hline 10 & $142^{\mathrm{b}} \pm 16.058$ & $115^{\mathrm{c}} \pm 24.941$ & $196^{\mathrm{a}} \pm 19.453$ & .034 & $* *$ \\
\hline 11 & $169 \pm 9.973$ & $159 \pm 26.341$ & $135 \pm 12.674$ & .413 & NS \\
\hline 12 & $192 \pm 11.173$ & $201 \pm 25.459$ & $168 \pm 18.160$ & .468 & NS \\
\hline 13 & $217 \pm 11.066$ & $220 \pm 34.358$ & $258 . \pm 27.107$ & .482 & NS \\
\hline 14 & $195 \pm 9.221$ & $246 \pm 31.390$ & $261 \pm 20.636$ & .122 & NS \\
\hline 15 & $187 \pm 34.345$ & $242 \pm 14.592$ & $245 \pm 22.023$ & .203 & NS \\
\hline 16 & $295 \pm 62.559$ & $253 \pm 22.801$ & $301 \pm 34.464$ & 699 & NS \\
\hline 17 & $400 \pm 31.168$ & $379 \pm 13.427$ & $392 \pm 27.323$ & .842 & NS \\
\hline 18 & $440 \pm 42.418$ & $345 \pm 36.368$ & $419 \pm 34.698$ & .202 & NS \\
\hline 19 & $75^{c} \pm 25.820$ & $281^{\mathrm{a}} \pm 61.234$ & $180^{\mathrm{b}} \pm 38.829$ & .015 & $* *$ \\
\hline 20 & $81^{c} \pm 13.527$ & $136^{\mathrm{b}} \pm 12.079$ & $167^{\mathrm{a}} \pm 13.222$ & .001 & $* *$ \\
\hline 21 & $80^{\mathrm{b}} \pm 14.475$ & $173^{\mathrm{a}} \pm 13.714$ & $170^{\mathrm{a}} \pm 14.286$ & .001 & $* *$ \\
\hline
\end{tabular}

NS $=$ Non-Significant, Values indicate mean \pm Standard Error

Table 4. Weekly live weight gain (g/bird) of White, Black and Bronze color types of female Turkey

\begin{tabular}{lccccc}
\hline $\begin{array}{l}\text { Age } \\
\text { (weeks) }\end{array}$ & White & Black & Bronze & P-value & $\begin{array}{c}\text { Level of } \\
\text { significance }\end{array}$ \\
\hline 5 & $31 \pm 3.441$ & $36 \pm 2.213$ & $34 \pm 1.010$ & .397 & NS \\
6 & $103 \pm 1.063$ & $100 \pm 2.091$ & $102 \pm 2.535$ & .520 & NS \\
7 & $51 \pm 5.464$ & $53 \pm 11.041$ & $56 \pm 13.248$ & .939 & NS \\
8 & $219 \pm 13.671$ & $224 \pm 17.749$ & $161 \pm 30.128$ & .103 & NS \\
9 & $66 \pm 13.605$ & $75 \pm 31.640$ & $58 \pm 21.132$ & .878 & NS \\
10 & $124 \pm 24.158$ & $110 \pm 29.665$ & $184 \pm 17.227$ & .101 & NS \\
11 & $138 \pm 30.095$ & $136 \pm 19.500$ & $101 \pm 9.999$ & .415 & NS \\
12 & $188 \pm 19.989$ & $137 \pm 31.581$ & $130 \pm 10.228$ & .159 & NS \\
13 & $106^{\mathrm{c}} \pm 28.370$ & $190^{\mathrm{a}} \pm 21.861$ & $157^{\mathrm{b}} \pm 13.924$ & .049 & $* *$ \\
14 & $160 \pm 15.887$ & $143 \pm 23.414$ & $167 \pm 11.488$ & .640 & $\mathrm{NS}$ \\
15 & $148 \pm 14.214$ & $196 \pm 24.887$ & $220 \pm 22.467$ & .075 & $\mathrm{NS}$ \\
16 & $214 . \pm 16.014$ & $165 \pm 25.671$ & $250 \pm 11.339$ & .017 & $\mathrm{NS}$ \\
17 & $220 \pm 19.100$ & $210 \pm 31.604$ & $251 \pm 31.504$ & .565 & $\mathrm{NS}$ \\
18 & $279 \pm 56.510$ & $290 \pm 50.178$ & $307 \pm 37.047$ & .916 & $\mathrm{NS}$ \\
19 & $87 \pm 64.465$ & $23 \pm 78.6587$ & $13 \pm 39.758$ & .674 & $\mathrm{NS}$ \\
20 & $77 \pm 16.506$ & $103 \pm 37.469$ & $105 \pm 12.038$ & .678 & $\mathrm{NS}$ \\
21 & $73 \pm 15.951$ & $118 \pm 34.481$ & $111 \pm 13.780$ & .360 & $\mathrm{NS}$ \\
\hline
\end{tabular}

NS $=$ Non-Significant, Values indicate mean \pm Standard Error 
In recent published data showed an average weekly weight gain of $107.1 \mathrm{~g} / \mathrm{bird}$ by providing ad libitum feed up to 36 weeks of age (Elizabeth et al., 2013). Karki (2005) carried an experiment might be considering the locally available heritage turkeys in Nepal and observed an average weekly live weight gain of $194.5 \mathrm{gm} / \mathrm{bird}$ at 20 weeks of age. An average weekly gain of $286.09 \mathrm{~g} /$ bird was also stated by Erener et al. (2006). All these results are almost resembled to the weight gain found in present observation. However, Waibel et al. (2000) conducted experiment with male hybrid turkeys and found weekly average weight gain of $680 \mathrm{~g} / \mathrm{bird}$. Almost similar weight gain was mentioned by Ersoy et al. (2006), who also used meat type hybrid turkeys in the study. Thus, it is likely that the hybrid turkeys gained almost 2-3 times higher weekly body weight as compared to local heritage type birds.

\section{Feed conversion ratio}

The feed conversion ratio (FCR) of three color types of turkey receiving same diet has been shown in Fig. 1. No significant differences were found in FCR for the three color types. The bronze color showed numerically lowest FCR value (3.5) compared to black (4.0) and white (4.5) color types. Several published reports suggest the average FCR for turkeys raised upto 20 weeks of age is approximately 2.729 (Austic and Neshein, 1990; Waibel et al. 2000; Prasad, 2000), which is slightly lower value as compared to the FCR found in current study, suggesting that the birds considered in present study utilize feed less efficiently. It can be noted that the turkeys used in present study were not provided ad libitum feed, which might be one of the key factors that caused poor FCR. Results of a study conducted at the Southern part of India showed almost similar FCR value (3.40) as observed in present study (www.tamilnadu farms.com). As it has been mentioned earlier that the mixed color unsexed birds used in the study were collected from a local farmer in Bogra, probably introduced from neighboring country, thus the FCR values were almost close to the Indian observation. In a recent research report of Przywitowski et al. (2016), almost similar FCR value of 3.06 at 18 weeks of age was stated. In Bangladesh, since the turkey has been introduced recently, as the specialized species of fowl and is expanding quickly at small and medium scale farming, however specialized feed formulae based on the nutrients required of heritage turkeys yet has not been developed. Thus, broiler starter and grower feed at initial stage, and later they supplied layer grower during growing followed by layer- layer diet during laying period. It has been well reported that the nutrients requirements of heritage turkey, protein in particularly is much higher (approximately 28\%) than the broiler diet $(22 \%)$. Thus it's most likely that the FCR of experimental birds found in current study can be improved once a specific diet is formulated and supplied to the birds satisfying all required nutrients, specifically the diet ensuring high level of protein.

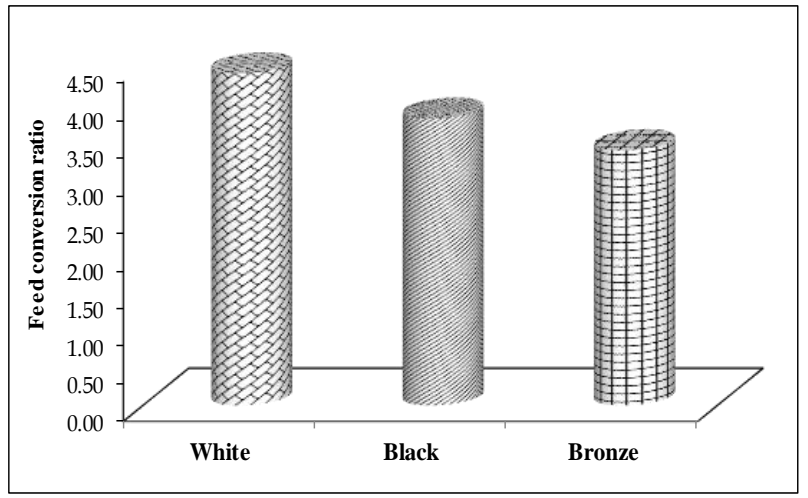

Fig. 1. FCR of White, Black and Bronze Turkeys under semiintensive system

\section{Bird's survivability}

Survivability and mortality of three color types of turkey under semi-intensive system is shown in Fig. 2. Overall mortality percentage was $8.70 \%$ which is within the range 5-30\% reported by Sampath (2012). A total of 4 turkeys of which 3 were under the Black color group and rest 1 belong to Bronze were died during 21 weeks of experimental period indicating that the survivability under semi intensive system of three different color types, White, Black and Bronze were 100\%, $88.46 \%$ and $91.67 \%$ respectively. Published data showed a mortality of $2.46 \%$ birds at 10-13 wk of age (Yilmaz et al. 2011). Among the dead birds, three died at $11^{\text {th }}$ weeks of age and the rest one died at $14^{\text {th }}$ weeks of age.

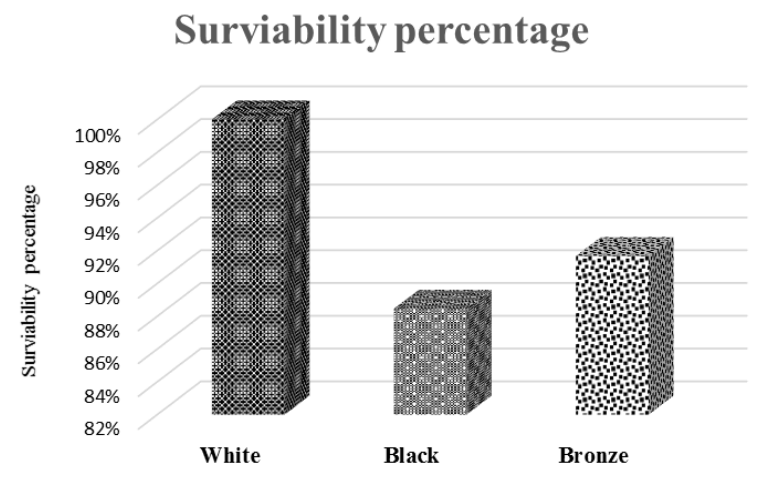

Fig. 2. Survivability of White, Black and Bronze color types of turkey under semi intensive system

All the 4 birds died during the experimental period were sent to the Department of Pathology, BAU, Mymensingh for post-mortem examinations. The birds were infected with Mycoplasma-E. Coli complex (M C Complex) however the problem could be overcome quickly with necessary treatment.

\section{Conclusion and future remarks}

Based on the results of present study, it can be concluded that the live weight, live weight gain, feed intake and feed conversion ratio and survivability of White, Black and Bronze color type of heritage turkeys under semi intensive system were almost similar. Turkey is gaining popularity among farming community for its higher meat production potential, low production cost and creating option for self- employment opportunities 
in Bangladesh. Since the birds have already proved their ability under semi-intensive rearing system in rural areas, further study should be undertaken with various levels of supplementations to increase the profit margin. Production of quality poults is the major challenges in Bangladesh. Small and medium scale farmers are producing poults indiscriminately, resulting unfair consequences. Thus, relevant sectors of the government, research and educational institutes, non-government organizations and enthusiastic investors should come forward and work together in a collaborative manner to ensure the production of quality poults.

\section{References}

Ahmed, M., Rao, R., Mahesh, P.S., Ravikumar, K., Ahmed, S. and Nallappa, P., 2009. Turkey farming guide. Central poultry development organization, (southern region) Hessarghatta, Bangalore- 560088.

All products require an annual contract. Prices do not include sales tax (New York residents only). (n.d.). Projected meat consumption in U.S. by type, 2026 | Statistic. Retrieved from https://www.statista.com/statistics/189222/averagemeat-consumption-in-the-us-by-sort/

Asaduzzaman, M., Salma, U., Ali, H.S., Hamid, M.A. and Miah, A.G., 2017. Problems and prospects of turkey (Meleagris gallpavo) production in Bangladesh. Research in Agriculture, Livestock and Fisheries, 4 (2): 77-90. https://doi.org/10.3329/ralf.v4i2.33719

Austic, R.E., Neshein, M.C., 1990. Poultry production. 13th edition. KM Varghese Company, Bombay, India. 622 p. PMid:2231025

Besbes, B., 2009. Genotype evaluation and breeding of poultry for performance under sub-optimal village conditions. World's Poultry Science Journal, 65: 260-271. https://doi.org/ $10.1017 / \mathrm{S} 0043933909000221$

Bhanja, S.K. and Majumdar, S., 2001. Formulation of turkey feed. In: Modern turkey production and management (AKD Roy, ed). Turkey Research Unit, Central Avian Research Institute, Izatnager, India. pp. 49-52.

Das, S.C., Chowdhury, S.D., Khatun, A., Isobe, N., Nishibori, M., Yoshimura, Y., 2008. Poultry production profile and expected future projection in Bangladesh. World's Poultry Science Journal, 64: 107-125. https://doi.org/10.1017/ S0043933907001754

Elizabeth, P., Camacho-Escobar, M.A., Ávila-SerranoJaime, N.Y., Ledezma, A., Sánchez-Bernal, E.I., Rodríguez-dela, T.M., Reyes-Borques, V., 2013. Productive evaluation of slowgrowing Mexican turkeys with different diets in confinement. Open Journal Animal Science, 3(1): 46-53. https://doi.org/10.4236/ojas.2013.31007
Erener, G., Ocak, N., Garipoglu, A.V., Sahin, A., Ozturk, E., 2006. Feeding Turkey Poults with Starter Feed. AsianAustralasian Journal of Animal Science, 19(1): 86-90. https://doi.org/10.5713/ajas.2006.86

Ersoy, E., Mendeş, M., Aktan, S., 2006. Growth curve establishment for American Bronze turkeys. Tierz Dummerstorf, 49(3): 293-299.

Food and Agriculture Organization 2012. FAOSTAT database. Accessed Sep. 27, 2012. http://faostat.fao.org.GilD. J. Leighto A. T.Jr. 1984. Effects of light environment and population density on growth performance of male turkeys. Poultry Science, 63: 1314.

Islam, M., Begum, Ismat, Kausar, A.K.M., Hossain, R., Kamruzzaman, M., 2015. Livelihood improvement of small farmers through family poultry in Bangladesh. International Journal of Business, Management and Social Research. 01. 61-70.10.18801/ijbmsr.010215.07.https://doi.org/10.18801/ ijbmsr.010215.07

Karki, M., 2005. Growth, Efficiency of Feed Utilization and Economics of Different Rearing Periods of Turkeys, Nepal Agriculture Research Journal, 6.

Ogundipe, S.O. and Dafwang, I.I., 1980. Turkey Production in Nigeria. National Agricultural Extension Research and Liaison Service (NAERLS) Bulletin No. 22. pp 2-22.

Prasad, D., 2000. Poultry Farming. 2nd edition. Kalyani Publishers, New Delhi, India.

Przywitowski, M, Mikulski, D., Zdunczyk, Z., Rogiewicz, A., Jankowski, J., 2016. The effect of dietary high-tannin and low-tannin faba bean (Vicia faba L.) on the growth performance, carcass traits and breast meat characteristics of finisher turkeys.

Saleque, M.A., 2010. Livestock and Livelihood- The role of BRAC in livestock development in Bangladesh, presented in Review of Livestock Research Programs and Preparation of Future Research organized by BRAC.

Sampath, K.T., Mech, A., Ghosh, J., Suganthi, R.U. and Roy, K.S. 2012. Turkey farming: A profitable enterprise. National Institute of Animal Nutrition and Physiology, Adugodi, Bangalore. Website: http://www.nianp.res.in

Singh, H. and Moore, E.N. 1972. Livestock and poultry production. 2nd Edition. Prentice Hall of India Private Limited, New Delhi, India.

Waibel, P.E., Carlson, C.W., Brannon, J.A., Noll, S.L., 2000. Limiting amino acids after methonine and lysine with growing turkeys fed low-protein diets. Poultry, 79: 1290-1298. https://doi.org/10.1093/ps/79.9.1290 PMid:11020074

Yilmaz, O. Denk, H., Kucuk, M., 2011. Growth performance and mortality in Hybrid Converter turkeys reared at high altitude region. Bulgarian Journal of Agricultural Science, 17: 241-245. 